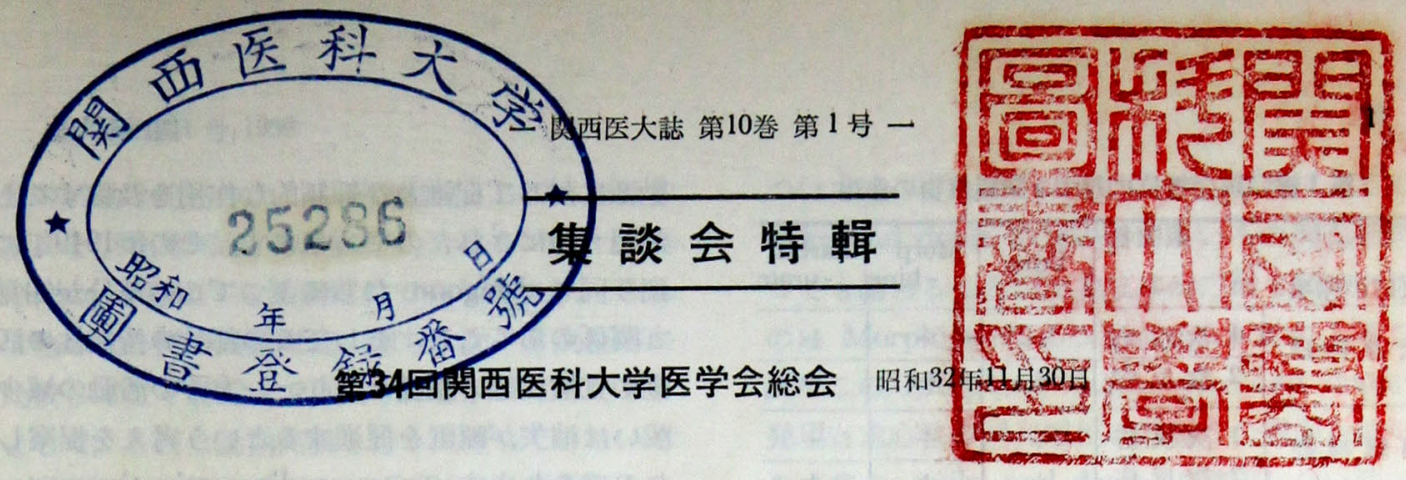

薬理学的に観た意識消失の機構

関西医科大学薬理学教室

$$
\text { 安原基弘 }
$$

\title{
Consciousness and Drug Action
}

\section{Motohiro Yasuhara}

Department of Pharmacology, Kansai Medical School

意識という言葉は現在生理学者や精神医学者な どそれぞれの分野に抏いて，或いは久その研究者 個人の立場からいろいろの概念が与えられており ますがままだはつきりした定義を下すととは困難 であります、けれども私がこてで取上げますのは てのようなむゔかしい意味の意識についてではな く, 從来楽理学に打いて対象とされている大ざつ ぱな意味での意識の消失, 即ち動物が周囲の状況 に対して全く注意をはらわなくなるような状態を 生ずる薬物の作用機序について，私が今までに行 つて来ました研究を中心として述べてみたいと思 うのであります。

現在知覚を対象とした薬物の作用機序の研究に とつて最も優れた方法は誘発電位を対象とした方 法でありますけれども, との研究には通常求心 性の 1 次, 2 次反応を始めとして, この他に reverberating response, recruiting response, local cortical response などが研究の対像とされて打り ます.とれらの研究は総て動物を Horsley-Clarke の装置に固定して行われたものでありますが，て

の Horsley-Clarke の装置は刺激電㥛や誘導電極 を中枢神経内の特定の㑬所に正確に挿入出来る装 置であります。このようにして得られた活動電位 の発生機構については現在 Eccles の説明が広く 採用されて扣りまして, 例を local cortical resp- onse にとりますと，皮質表面に近い神経組織の 興在する時には電流は深首より表首に向つて流 れ，そのために活動電位は表面誘導によつて negative な phase として記録されるのでありま す。ついで潹首が興售するようになりますが，そ の時には逆に positive な phase として記録する ことが出米るのであります. Eccles は local cortical response の発生機構をこのように説明して 扣りますが，いつれにしてもてのような活動电位 を対象として，乙れ亿対する薬物の作用態度から 種々の薬物の作用部位を正確隹知ることが出来る のであります。この詳細をくわしく述べてもよい のですが，それがての目的でもありませんので， このうち最も重要な Morphine の求心性の誘発 電位に対する作用についてのみ述へてみますと， Morphine は求心性の伝導路䘮通つて上昇与る 1 次，2次反応のうちで下等な protopatic なもの だけ芷衡で遮断することが明らかにされて打り

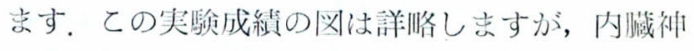
経を刺激しますと, 大胹皮質では大侑 3 相性の電 位の小さな 1 次反応とこれよりも電位の大きい 2 次反応とが認められます。とてろがこの誘発電位 は Morphine を $6 \mathrm{mg} / \mathrm{kg}$ 静脈内に注射しますと 消失してしまうのであります。てれと同様の現象 は脊艏から誘導した場合にも認られて扣りまし 
第 1 表 侤発電位に対する諸㮔薬物の作用

\begin{tabular}{|c|c|c|c|c|}
\hline \multicolumn{2}{|c|}{ 反応の種類 } & Ether & $\begin{array}{l}\text { Morp } \\
\text { - hine }\end{array}$ & $\begin{array}{l}\text { Barbit } \\
\text { - urate }\end{array}$ \\
\hline \multirow{2}{*}{ 坐胃神経 } & 1 次反応 & - & - & - \\
\hline & 2 次反応 & + & - & - \\
\hline \multirow{2}{*}{ 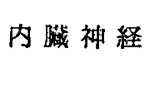 } & 1 次反応 & + & + & + \\
\hline & 2 次反応 & + & + & + \\
\hline \multicolumn{2}{|c|}{ reverberating response } & + & + & + \\
\hline \multicolumn{2}{|c|}{ recruiting response } & + & + & + \\
\hline \multicolumn{2}{|c|}{ local cortical response } & + & + & - \\
\hline
\end{tabular}

註：十は抑制作用を示す

て，てのようにしていろいろの誘発電位に対する 薬物の作用からその薬物の作用部位を知るととが 出来るのであります。そこで次にての誘発電位に 対する Ether, Morphine, Aminopyrine の作用 を一括してみますと表のようになるのでありまし て, Morphine の鎮痛作用は今述べました求心路 に対する作用によるものではないかと考えられる のでありますが，ての鎮痛の問題はさて括きまし て，てのうち適量の投与下に意識の消失を来す浆 物は何かと申しますと，それは Ether だけであり まして, Morphine や Aminopyrine は適量の投 与下には意識の消失を来すととは諗められており ません、しかし Morphine はてれらの反态に対 して, epicritic なものの含まれる求心性の活動鼠 位を除き，てれを総て抑制しております。てのて とは逆にいいますとてれらの反灾の中に意識の消 失と直接関係のあるものは存在しないというとと になるのでありまして, 事実 Ether と同様意識の 消失を来す Barbiturate は適量の投与下にてれら の反忘をかえつて増大するてとが知られておりま す.

それではこの Ether や Barbiturate のような 菢識の消失を来す蒋物の作用部位はどてかという てとが問題となるわけでありますが，てれは絬果 を先に述べますと, ascending reticular activating systemであるといわれて打ります.この ascending reticular activating system についてはまだよく 知られていないかと思いますが，てれは主に脳幹 の網㥞体によつて形成されて㧍りまして，ての部 分の機能については坡初 Magounたちによつて速

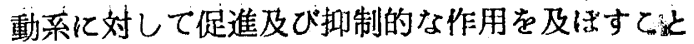
が明らかにされたのであります。にの後1949年に 到り同じ Magoun たちによつてての部分が知覚 と関係のあるとと，そしてての部分の持続性の活 動が覚醒状癿の基脿となり，一方その活動の诚少 或いは消失が隀眠を促進するという考えを提案し たのであります.この ascending activating syste$\mathrm{m}$ はその高さの主知覚路よりの側枝から impulse を受けて興奪するものでありまして，あらゆる種 類の知覚により等しく興奞するてとが明らかにさ れて打りますが，初めこの system は兴幹絽様体 より Jasper のいう diffuse thalamocortical projection system を経て大脸皮筫に放散すると考え られて扣りました。 とてろが最近薬物に対する作 用態度加らこの上向路は Jasper の diffuse thalamocortical projection system を通るのではな くて， thalamus を通るにしてもこれとは暴つた 組織であつて脳幹網様体と同樣の構造を有する組 織を介して放散するというとと，即ち diffuse thalamocortical projection system とは別の経路 により放散するてとが明らかにされでります。 㕛最近ではこの ascending activating system は 大脳皮質より逆に神経線維を受けることが明らか にされて扣ります．要するにての部分は大脳皮質 との密接な相関関係によつて高次な精神活動に関 与するととが考えられるのであります。てのよう に ascending activating system は精神活動と関 係があるのでありますけれども，てれが最初この ような機能と関係のあるととは脳波に対するての 部分の刺湤と破壊の影響から考えられるようにな つたのであつて，乙の部分を刺激しますと，筧醒 反応と同様の速波の出現するととが知られて扣り ます．又との部分の破壊は渪眠時と同様の波型の 出現するととが明らかにされております。ですか らてのような覚醒反応を目標として，てれに対す る薬物の影響を調べるととにより，その作用部位 を知ることが出来るのであります。この覚醒反応 の刺激闘值に対する浆物の作用の実験汃らは

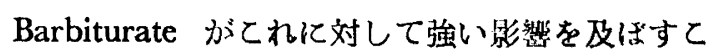
と年明らかにされております。このようにとの ascending activating system の䣦さは覚醒友応に よつて知ることぶ出米るのでありますが，との部 
分の活動は首述のように活動電位としても記録す ろととが出来ろのであります。ところでての system を経由する活動電位でありますが，乙れ は他の求心性の活動鼠位, 即ち 1 次, 2 次反応に 比較してでく最近まで見出されなかつたのであり まして、てれは動物実験を行うに際していろいろ の麻酙桬を使用するために，それらの薬物により この system がその機能を失つていたためである といわれて抢ります，ての活動電位も Magoun たちによつて初めで記録されて打りますが, 最近 では覚醒反応よりもこの活動電位に対する薬物の 作用の方がよく調べられて打ります。そしてての ような研究から Ether や Barbiturate のような 麻酥薬や青酸カリ, 酸素欠乏或いは低任糖のよう な状態の際, 主知覚路の誘発電位よりも ascending activating system を上行する誘発電位の強く抑制 されるてとが明らかにされております。てのよう に ascending activating system の誘発電位はい ろいろの状態により抑制されますが，とてろがて れとは逆に Strychnineや Metrazol のような興

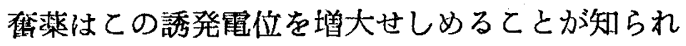
て扣ります，以上述べて米ましたてとから，意識 の消失を来す薬物は 1 次反応の伝学路である主知 筧路には大した影響を及ばすととなく. ascending activating system に強い影響を及ばすととが考 えられるのでありますが，てれは意識の消失を来 すいろいろの疾患の場合にもいえるのでありまし て, 糖尿病や尿素症の時の coma の意識消失も乙 の system の障碍によるととが考えられるのであ ります。ですからてのような場合の対症療法とし ては今述べをてとから分るようにての system に 対して刺激的な作用を有する Metrozol のような 興俩薬が与えられればよいわけであります。

てのようにいろいろの臨床疾㭧の意識消失は ascending activating system の障碍によること が考えられるのでありますが，その他に臨床では てれとは全く異つた機序によると思われる意識の 消失が知られて打ります。をれは小発作の際の意 識の消失であつて，乙の場合大脳皮質には spike and dome と呼ばれる特異な波型の脳波が諗めら れておりますが，てのような機序による意識の消 失は澘理学的にも考えられますので, 次にてれに
ついて述べてみたと思います，获物によるての

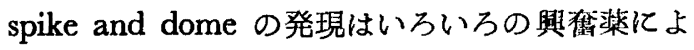
つても認めることが出来ますが，最も興味のある のは Morphine によるものであります.そこで 次にこの Morphine による spike and dome の 発現と求心性の誘発電位の抑制との関係を調へて みますと, spike and dome の発現しない例では 求心性の誘発電位は抑制されることなく, spike and dome の発現している例に於いてのみての抑 制が強く認められているのであります。即ち大脳 皮質に spike and dome が現われて来ますと， 求心性の誘発電位は抑制されるようになるのであ りまして，ての実験から Morphine は spike and domeの現われる量では求心路に対してprotopatic なもののみでなく, epicritic なものをも抑制する ことが分るのであります。そしてての場合 Morphine は図に示す如く spike and dome の focus に作用して，間接的に求心路を抑制するととが知 られるのであります。即ち薬理学的には前述心゙ま した ascending activating system に対する直接 作用による意識の消失の他に，今述べたような間 接的な意識の消失が考えられるのであります。も つともこの間接作用の場合の意識の消失も終局的 には ascending activating system の麻瘦による ことが推測されるのであります。いずれにしまし ても意識の消失にてのような大别して 2 つの case のあることはいろいろの疾患の意識消失の萊物治 療の際に当然想起されねばなら妋とでありまし て, 特に spike and dome は Barbiturate 投与 下によく認められるということが咸られて打りま

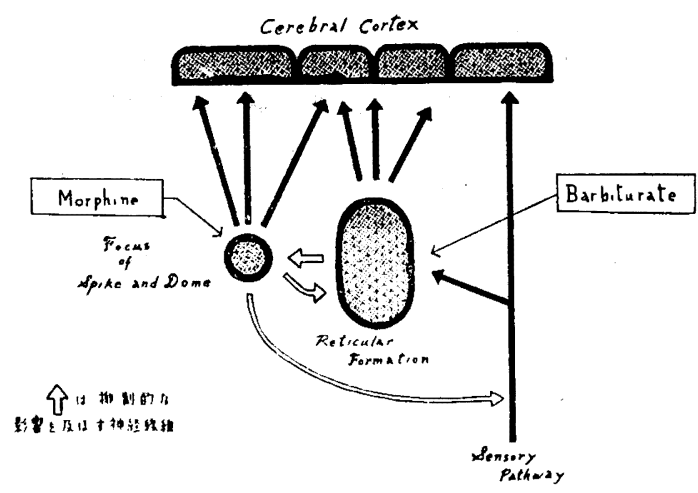

第 1 図 Barbiturate と Morphine の意践 消失機構芭示す図 
すので，てのととは実際治療上にとつても非常に 重要な問題ではないかと思います。乙れと同様の 問題につきましては先に東京医科燐科大学の島本 教授が疫痢の際の意識消失に高張ブド一糖を投与 するととによつて spike and dome の出現する てとを指摘されて打りますが，てのような場合に は意識消失に対する治療がかえつて逆の效果を導 くことがありうるわけであります，分り易くする ために更にくわしく説明しますと， ascending activating system の麻瘦による意識消失の場合， spike and dome の focus は興公し易くなつてお りますので，そのような場合にはての focus に強 い作用を有する薬物を与えますと，それがたとえ ascending activating system 亿対し強い興㮐作用 を有するものであつても activating system より も spike and dome の focus 亿対する作用の強 く出てくる可能性があるのでありまして，その場 合, 意識の消失はかえつて強められるてとがある
わけでず.ですからてのような ascending activating system の麻痺の場合の意識消失にとつて最 もよい治療薬は，先にも述べましたようにての

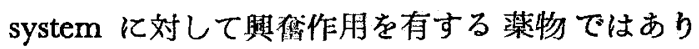
ますけれども，てれは壮来得る限り spike and dome の focus に対しては作用しないもの, むし ろこれに抑制的な作用を有する楽物であるてとが 望まれるわけであります。一方ての spike and dome の focus の興奞による意識の消失には，同 じ理由によりまして ascending activating system の麻瘦の場合とは逆に spike and dome の focus の興偣を抑制し, activating system に対しては むしろ刺激的な作用を有する楽物であるととが望 ましいわけであります，現在てのような理想的な 意味での薬物はみあたりませんけれども，適当に 薬物を配伍することによつて或る程度ての目的を 達するととが出来るのではないかと思う次第であ ります。

\title{
副腎除去による炎症反応心変形について
}

\author{
関西医科大学病理学教室 \\ 平田をと总
Studies on the Modified Inflammatory Cell Reactions of the Incomplete Adrenalectomized Animals \\ Motoe Hirata (Assistant Professor) \\ Department of Pathology, Kansai Medical School
}

私は 1943 年来炎症細胞に関する研究に着手し た. 当時の炎症細胞論は, 結合織其の他の閒葉細 胞についての Möllendorff, Maximow, 泞野及び Sabin 等の侵れた研究があつた少尚, 極めて不倩 であつた，単球と組繶球とに関する諸問題もその 重要課題であつた，そてで我々は先つ組織内睹球 の問題を追究しようと考えて, 腹水細胞及び皮下 組織内細胞を研究材料として採用し, この際, こ れらの細胞寺顺に形態兴的に研究するのみなら

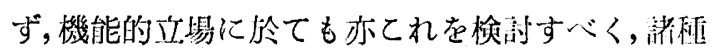
の血液学的検查術式芯志用するりにした。当時咴
に Sabin は遊離細胞に関しては, 中性赤・ヤ一 ヌス緑を以てする超生体観察法を考案していた が，ての方法を固䇥叙抹染色法と併用する北によ り,よく細胞の機能形熊学的特徵をとらえる事が 出来た，そこで我々は大綱，皮下結合織の如き溥 膜に対しても，Sabin 法に準じた超生体観察法 と, マイ,ギムザ染色法を抬した固定伸展観祭法

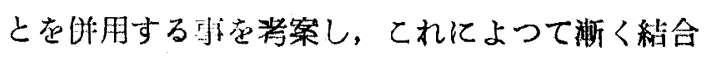

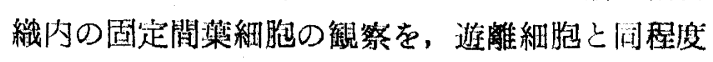
にまでなし得る事が汁るようになつた。 即ち、こ の方法によつて先つ絬合織内組織球の超生体䚒祭 